\title{
HEAD AND NECK SWELLING: A CYTOPATHOLOGICAL PERSPECTIVE IN A HOSPITAL BASED STUDY
}

\author{
Sujan Shrestha ${ }^{1 *}$, Dinesh Khadka ${ }^{2}$, Sujita Bhandari ${ }^{3}$
}

\section{Affiliation}

1. Consultant, Department of Pathology, National Academy of Medical Sciences (NAMS), Bir Hospital, Nepal

2. Pathologist, Department of pathology, Parco health care, Qatar

3. PGY-1 resident In Pathology, NYU Langone Long Island Hospital, Mineola, Newyork, USA

\section{ARTICLE INFO}

\section{Received : 24 February, 2021 \\ Accepted : 10 July, 2021 \\ Published : 04 November, 2021}

(C) Authors retain copyright and grant the journal right of first publication with the work simultaneously licensed under Creative Commons Attribution License CC - BY 4.0 that allows others to share the work with an acknowledgment of the work's authorship and initial publication in this journal.

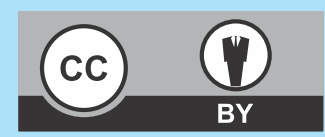

\section{ORA 251}

DOI: https://doi.org/10.3126/bjhs.v6i2.40319

\section{* Corresponding Author \\ Dr Sujan Shrestha \\ Consultant \\ Department of Pathology,}

National Academy of Medical Sciences (NAMS), Bir Hospital, Nepal Email: sujanshresthadr@gmail.com ORCID: https://orcid.org/0000-0003-1987-1597

\section{Citation}

Sujan Shrestha, Dinesh Khadka, Sujita Bhandari. Head and Neck Swelling: A Cytopathological Perspective in A Hospital Based Study. BJHS 2021;6(2)15. 1460-1465.

\section{ABSTRACT}

\section{Introduction}

Fine Needle Aspiration Cytology is a simple, relatively less painful, cost-effective minimal invasive procedure commonly employed in the evaluation of head and neck swellings. There are limited studies on cytological findings of head and neck swelling in Nepal.

\section{Objectives}

The objective of this study was to study cytological findings of head and neck swellings. This study further intends to classify the nature of the swelling and use standardized international reporting system wherever required.

\section{Methodology}

This is a retrospective hospital-based study done in the Department of Pathology at the Helping Hands Community Hospital, Kathmandu between 1 January 2019 and 32 December 2019. Slides of all FNAC from head and neck swelling done during this period was retrieved and evaluated for the study. Chi-Squared $(\chi 2)$ test was used to investigate the significance of epidemiological and cytological parameters.

\section{Result}

Males (56\%) had more head and neck swelling than females (44\%). The younger age group of less than twenty-five $(<25)$ years had more frequency of head and swelling followed by the older age group of more than fifty $(>50)$ years. The most common site for Fine needle aspiration was lymph nodes (58\%) followed by thyroid swelling $(23 \%)$. Salivary gland swellings were the least frequent (5\%). Of all the swelling, $17 \%$ of cases were attributed to malignant causes. Infective/Inflammatory causes (55\%) were the most common cause of lymph node swellings. Metastatic carcinoma was more prevalent in the older age group of more than fifty $(>50)$ years with a prevalence of $21 \%$ of total cases studies. Most of the thyroid swellings were found to be benign (58\%) whereas $16 \%$ of thyroid swellings belonged to the malignant category. The total numbers of salivary gland swelling were the least with $55 \%$ of cases having benign neoplastic etiology. Diagnosis of developmental anomalies like a thyroglossal cyst, lymphangioma, branchial cyst, though relatively less common (10\%) were also made with the help of cytologic studies.

\section{Conclusion}

Fine Needle Aspiration is a useful method to differentiate benign and infective cases of head and neck swelling from neoplastic cases.

\section{KEYWORDS}

FNAC, head and neck swelling, lymph node, malignancy, thyroid swelling. 


\section{INTRODUCTION}

Swelling on the head and neck region are chief complaints that bring patients to the hospital for Fine needle aspiration (FNA) procedure. Fine needle aspiration cytology (FNAC) is a cytodiagnostic method based on cytomorphological observation of cells obtained using a fine needle. Fine needle aspiration cytology is one of the first lines of investigation in the evaluation of any swelling as it is relatively easy, rapid, cost-effective and minimally invasive procedure. ${ }^{1}$ The utility of needle aspiration for diagnostic purposes has been discussed as early as 1847 by Kum. ${ }^{2}$ In 1930, Memorial Sloan Kettering centre rediscovered the utility of needle biopsy of head and neck mass but the procedure failed to get popularity as wide bore needle was attributed at that time for seeding of malignant cells. In 1950 the needle size was modified following which the number of morbidities associated with previous procedures showed significant reduction resulting in a resurgence in the use of FNAC. $^{3}$

The head and neck region consist of variable tissue types in close proximity rendering difficulty in incisional biopsy. In addition, wide range of primary and metastatic neoplasm are responsible for head and neck region swelling which makes FNAC more advantageous. The other significant benefits of FNAC include minimal physical and psychological pain, discomfort, elimination of a two-stage procedure for diagnosis and treatment. ${ }^{4}$ The objective of this study was to study cytological findings of head and neck swellings. This study further intends to classify the nature of the swelling and use standardized international reporting system wherever required. The purpose of this study was to evaluate the distribution and determine the spectrum of cytological findings inpatients presenting head and neck swellings in a community hospital.

\section{METHODOLOGY}

\section{Study design, population, and data collection}

A retrospective cohort study was conducted on the data obtained on all FNAC performed cases in the Department of Pathology at the Helping Hands Community Hospital, Kathmandu between 1 January 2019 and 31 December 2019. All the FNAC cases performed by the pathologists and imaging guided (Ultra sonogram guided or Computed Tomography Guided) FNA performed by the radiologists from the head and neck masses were included in the study population.

The FNAC slides were retrieved and evaluation was done by the primary author. Cases in which the cellular yield was poor and thus inadequate for evaluation were excluded from the study. The patient information report included the demographic information, anatomical location of the swellings, the severity of the case, and the procedure undertaken. The Bethesda system or reporting thyroid cytopathology was adopted while reporting thyroid FNAC and the Milan system for reporting salivary gland cytology was adopted while reporting salivary gland FNAC., ${ }^{5,6}$ Findings were further classified into specific infective/inflammatory, benign, suspicious, and malignant categories.

\section{Statistical analysis}

Data were organized for analysis in Microsoft Excel 2016 (Microsoft Corporation, Redmond, WA, USA) and the exploratory data analysis was performed. For convenience, the patient's age variable was categorized into three groups: younger age group ( $<25$ years), mid-age group (2550 years), and old-age group ( 50 years above).

Chi-Squared $(x 2)$ test was employed to investigate the significance of suitable epidemiological and cytological parameters. The level of statistical significance was set at $P<0.05$. Statistical analyses were conducted using functions available in the packages 'epiR', in R. ${ }^{7,8}$ The ethical clearance was obtained from the Helping Hands Community Hospital for the study.

\section{RESULT}

In a one-year study period, there were 154 cases, 87 (56\%) males and 67 (44\%) females. The younger age group of $(<25$ years) were the highest number of cases 64 (41\%) followed by the oldest age group 51 (33\%) (Table 1).

\begin{tabular}{|c|c|c|c|c|c|c|}
\hline \multicolumn{2}{|c|}{ Gender } & \multirow[t]{2}{*}{ Total cases } & & \multirow[b]{2}{*}{$>50 \mathrm{yrs}$} & \multirow[t]{2}{*}{ Total cases } \\
\hline Male & Female & & $<25 y r s$ & $25-50 y r s$ & & \\
\hline $\begin{array}{l}87 \\
(56 \%)\end{array}$ & $\begin{array}{l}67 \\
(44 \%)\end{array}$ & 154 (100\%) & $\begin{array}{c}64 \\
(41 \%)\end{array}$ & $\begin{array}{c}39 \\
(25 \%)\end{array}$ & $\begin{array}{c}51 \\
(33 \%)\end{array}$ & $154(100 \%)$ \\
\hline
\end{tabular}

Details of the location of anatomical location of swellings and number are summarised in Table 2. The most frequent cases were lymph nodes with 90 cases while 36 cases of gland swellings, 9 cases of salivary glands and 19 cases of soft tissues swellings were observed across the timeperiod.

\begin{tabular}{|c|c|c|c|c|c|c|}
\hline \multirow{2}{*}{ Site } & \multicolumn{2}{|r|}{ Sex } & \multicolumn{3}{|c|}{ Age } & \multirow{2}{*}{ Total (\%) } \\
\hline & Male & Female & $<25$ years & 25-50 years & $>50$ years & \\
\hline Lymph node & 56 & 34 & 39 & 22 & 29 & $90(58)$ \\
\hline Thyroid gland & 14 & 22 & 17 & 13 & 6 & $36(23)$ \\
\hline Soft tissues & 10 & 9 & 7 & 3 & 9 & $19(12)$ \\
\hline Salivary glands & 7 & 2 & 1 & 1 & 7 & $9(5)$ \\
\hline Total & 87 & 67 & 64 & 39 & 51 & $154(100)$ \\
\hline
\end{tabular}

The number of enlarged lymph nodes stratified by the description of the type of etiologies in the study period are summarized in Table 3. Infective/Inflammatory etiology which included tubercular lymphadenitis (Figure 1), granulomatous lymphadenitis, suppurative lymphadenitis (Figure 3) and Kikuchi lymphadenitis were the most common findings in younger age groups ( $<25$ years) whereas malignant cases (Figure 2) which included metastases of adenocarcinoma (Figure 4), squamous cells carcinoma, small round cell carcinoma, undifferentiated carcinoma were the most common findings in older age group ( $>50$ years). Reactive lymphadenitis are those groups 
of enlarged lymph nodes which revealed polymorphous lymphoid population of cells suggestive of various stages of maturation, with occasional tingible body macrophages. However, there were no a typical cells or morphological changes like granulomas formation, necrosis on cytologic examination. Regardless of the age, Tubercular lymphadenitis (34\%) was the most common cause of lymph node enlargement. The odds of lymph node cases for males was $1.75(95 \% \mathrm{Cl} 0.92$ - 3.36) times that of females.

Table 3. Number and incidence of enlarged lymph node etiologies stratified by age group $(n=90)$.

\begin{tabular}{ccccc}
\hline Age groups & $\begin{array}{c}\text { Infective/ } \\
\text { Inflammatory (\%) }\end{array}$ & Reactive (\%) & Malignant (\%) & Total (\%) \\
\hline$<25$ yrs & $24(48)$ & $13(65)$ & $2(10)$ & $39(43)$ \\
$25-50$ yrs & $17(34)$ & $5(25)$ & $0(0)$ & $22(25)$ \\
$>50$ yrs & $9(18)$ & $2(10)$ & $18(90)$ & $29(32)$ \\
Total & $50(100 \%)$ & $20(100)$ & $20(100)$ & $90(100)$ \\
\hline
\end{tabular}

Table 4.Number of thyroid swelling categorized based on the Bethesda reporting of thyroid cytology $(n=36)$.

\begin{tabular}{clcc}
\hline $\begin{array}{c}\text { Diagnostic } \\
\text { Category }\end{array}$ & Interpretation & $\begin{array}{c}\text { Number of } \\
\text { cases }\end{array}$ & $\%$ \\
\hline I & Inadequate & 4 & 11 \\
II & Benign & 21 & 58 \\
III & Atypia & 0 & 0 \\
IV & Suspicious for follicular & 2 & 6 \\
& neoplasm & & \\
V & Suspicious for malignancy & 3 & 8 \\
VI & Malignant & 6 & 17 \\
\hline & Total & 36 & $\mathbf{1 0 0}$ \\
\hline
\end{tabular}

Of the 50 infective/inflammatory pathologies, 31 cases (62\%) had tubercular etiology which was confirmed on the examination of stained slides. The remaining 19 cases (38\%) were those of granulomatous lymphadenitis 8 cases (16\%), acute suppurative lymphadenitis $8(16 \%)$ cases, and Kikuchi lymphadenitis $3(6 \%)$ cases.

The two cases in the younger age group ( $<25$ years) had findings suggestive of malignancy: one Hodgkin lymphoma and the other metastatic papillary thyroid carcinoma. Adult age group were more likely to suffer from malignancy than younger age group ( $\chi 2$ test statistic $11.635 ; d f=1 ; p<0.001$ ). Metastatic adenocarcinoma was the most common finding among the malignant causes. Of 20 malignancy cases, 19 cases revealed features of metastatic carcinoma and a case showed features of primary malignancy as Hodgkin's lymphoma. Metastatic adenocarcinoma was seen in 11 cases followed by squamous cell carcinoma in three cases. All the metastases were present in the elderly age group of $>50$ cases except for a single case of papillary carcinoma thyroid which was seen in the age group $<25$ yrs. Two cases were signed out as positive for malignancy since further categorization could not be done based on cytomorphology alone.

FNAC performed in 36 cases of thyroid swelling, of which 4 (11\%) cases were reported as inadequate for evaluation.
Twenty-one cases of 36 cases (58\%) were diagnosed benign which included lymphocytic thyroiditis, nodular colloid goiter, adenomatoid nodule, and subacute thyroiditis. Six cases $(16 \%)$ were reported as papillary carcinoma thyroid (Fig 5) and three cases (8\%) were reported for papillary carcinoma thyroid. Females were more likely to have thyroid swelling compared to males $\left(\chi^{2}\right.$ test statistic $5.924 ; d f=1 ; p$ $<0.01)$.

\begin{tabular}{|c|c|c|c|}
\hline $\begin{array}{l}\text { Diagnostic } \\
\text { Category }\end{array}$ & Interpretation & $\begin{array}{c}\text { Number of } \\
\text { cases }\end{array}$ & $\%$ \\
\hline 1 & Non-diagnostic & 0 & 0 \\
\hline II & Non-neoplastic & 1 & 11 \\
\hline III & $\begin{array}{l}\text { Atypia of undetermined } \\
\text { significance }\end{array}$ & 0 & 0 \\
\hline IV & Neoplasm & 6 & 67 \\
\hline V & Suspicious & 1 & 11 \\
\hline \multirow[t]{2}{*}{ VI } & Malignant & 1 & 11 \\
\hline & Total & 9 & 100 \\
\hline
\end{tabular}

Table 6. Number of soft tissue swelling cases present in different anatomical regions of the head and neck $(n=19)$.

\begin{tabular}{lcc}
\hline \multicolumn{1}{c}{$\begin{array}{c}\text { Types of soft tissue } \\
\text { swelling }\end{array}$} & Number of cases & $\%$ \\
\hline Thyroglossal cyst & 7 & 37 \\
Lymphangioma & 4 & 21 \\
Branchial cyst & 4 & 21 \\
Schwannoma & 2 & 11 \\
Granulomatous lesion & 1 & 5 \\
Epidermoid cyst & 1 & 5 \\
Total & 19 & 100 \\
\hline
\end{tabular}

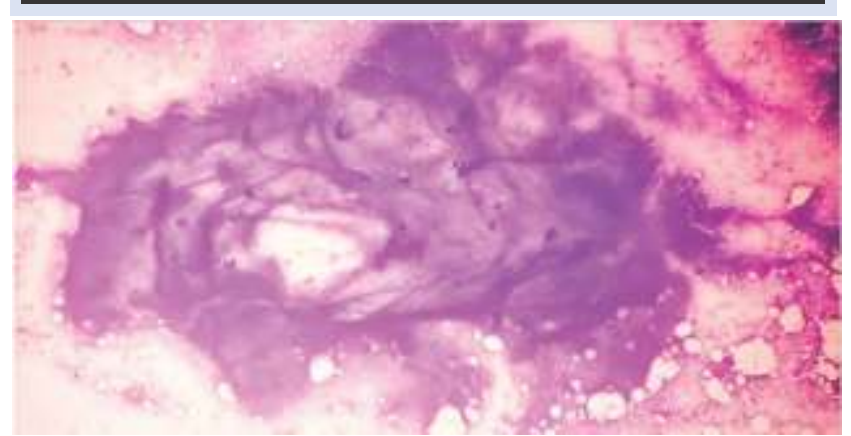

Figure 1: Tubercular lymphadenitis showing extensive areas of caseous necrosis. (MGG, 10X power)

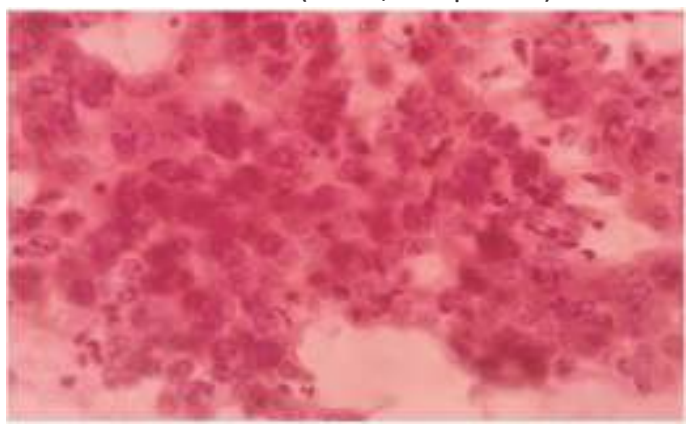

Figure 2: Malignant cells suggestive of metastatic carcinoma (Pap, High Power) 


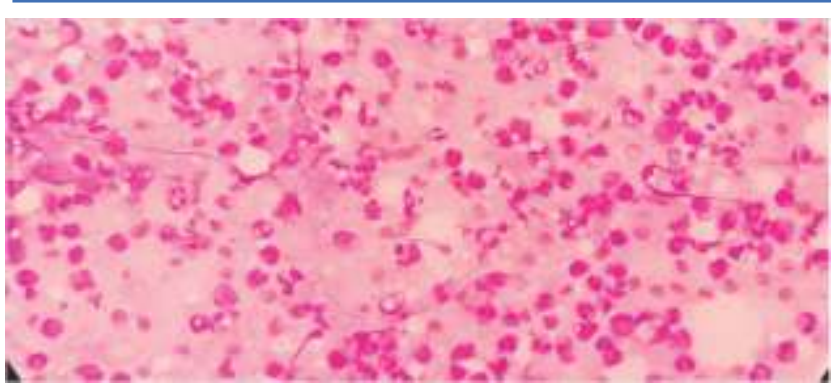

Figure 3: Suppurative lymphadenitis showing neutrophils and its debris. (MGG, Intermediate Power)

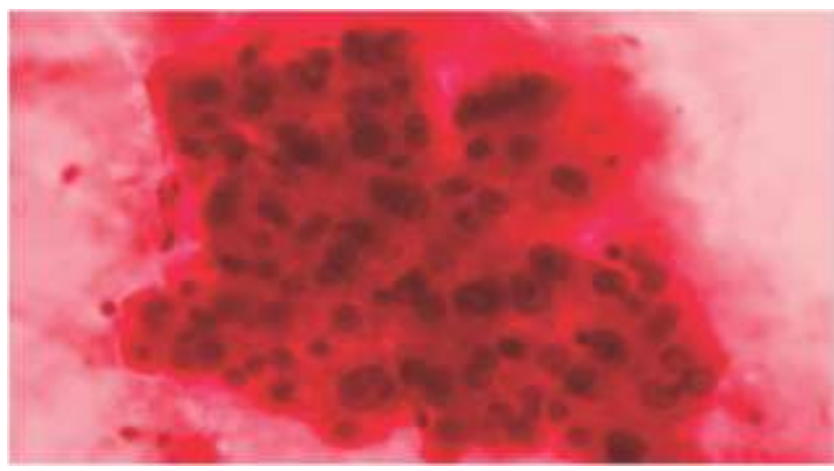

Figure 4: Metastatic tumor cells in lymph node. (Pap, High Power)

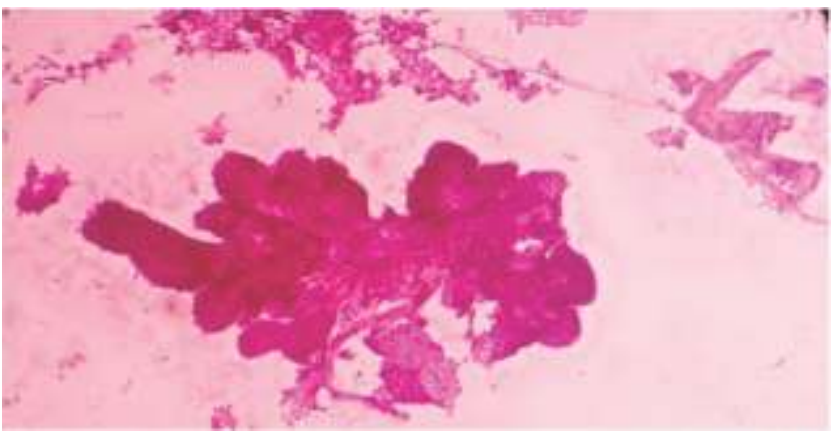

Figure 5: Papillary arrangement of tumor cells in papillary carcinoma thyroid. (Pap, Low Power)

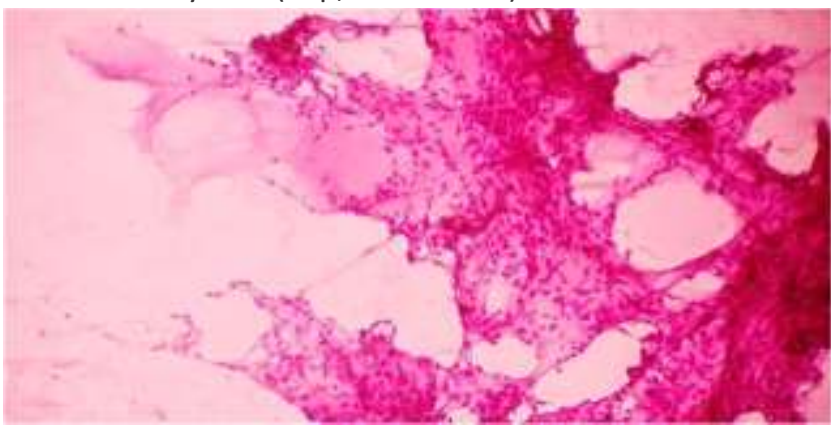

Figure 6: Myxoidstroma with bland cells in pleomorphic adenoma (Pap, Low Power).

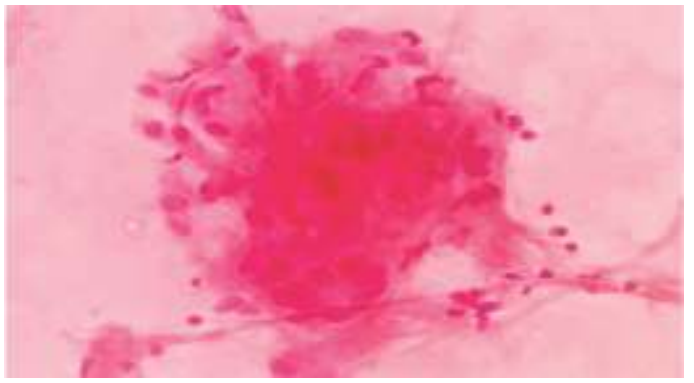

Figure 7: Granuloma (Pap, Intermediate Power)

\section{DISCUSSION}

The study illustrates the utility of FNAC at various anatomical locations. The majority of FNA specimens were obtained from the lymph nodes followed by thyroid swelling. The results from this study accords with previous studies that obtained majority of aspirates from the lymph nodes for FNAC. ${ }^{9}$ Consistent with the literature, this research found that adults have higher incidence of malignancy. ${ }^{10}$ This is likely due to the habit of smoking and tobacco chewing.

Another interesting finding is that females were more likely to have thyroid swelling compared to males. The finding was in consistent with Raina et al. and Kamra et al. who have demonstrated that genetic and environmental factors play role in thyroiditis in females. ${ }^{11,12}$

Clinical and radiological examination findings of head and neck masses are not always sufficient to decide on the further line of management. Cytological examination of the material obtained by FNA might prove to be an effective tool in deciding further line of management of these swelling. FNAC procedure is reported to have $76.5 \%$ specificity and $78 \%$ sensitivity for identifying malignant lateral cervical lesions. ${ }^{13}$ Regarding sensitivity and specificity of FNAC, a study reported sensitivity of $89 \%$ and specificity of $57 \%$ in neck lymph nodes, $64 \%$ sensitivity and $100 \%$ specificity in salivary gland swelling, $62 \%$ sensitivity and $86 \%$ specificity in thyroid gland swelling. ${ }^{14}$ The overall accuracy ratio, specificity, sensitivity, negative predictive value and positive predictive value of FNAC in the diagnosis of head and neck masses were $83 \%, 85 \%, 81 \%, 84 \%, 83 \%$ respectively. ${ }^{15}$

The study further supports the idea that FNA followed by biopsy has high overall accuracy. ${ }^{16}$ It has a wide array of uses and provides confidence to confirm malignancy even in a clinically suspicious lesion though it should be noted that procedures require experienced cytopathologists for perfect execution.

In this study, males were predominant over females which agree with those obtained by previous studies. ${ }^{17,18}$ In contrast to this, study by Singh et al. reported female predominance in their study. ${ }^{19}$

Akhavan-Moghadam et al. reported $41 \%$ malignant cases, $19 \%$ cases benign neoplasm and $40 \%$ cases non-neoplastic. ${ }^{20}$ This finding broadly supports the work of other studies in this area where metastatic carcinoma to lymph nodes was the most common type of malignancy. ${ }^{21}$

FNA of a thyroid nodule is indicated in various situation such as patient with clinical symptoms of thyroid cancer, nodules $>1 \mathrm{~cm}$ with at least two ultrasound criteria of malignancy. ${ }^{22}$ According to the guidelines developed by Perros et al. FNA is also indicated when nodules of any size with extracapsular extension or indeterminate cervical lymph nodes, nodules of any size in a patient with a history of neck radiation, history of well-differentiated thyroid cancer in more than two first degree relatives, medullary thyroid carcinoma or multiple endocrine neoplasias (MEN) TYPE 2, increased calcitonin level. ${ }^{22}$ 
The sensitivity of thyroid carcinoma detection is approximately $60-90 \%$ (in some cases up to $100 \%$ ) and the specificity of 60 $100 \%$ in the hand of an experienced cytologist. ${ }^{23}$ The molecular genetic analysis of the FNA specimen will further improve the diagnostic accuracy with the identification of additional genes involved in the pathogenesis of thyroid cancer.

Reporting of salivary gland cytology has been a challenging job because of the resemblance of neoplastic cells to normal salivary gland element, the heterogeneous nature of salivary gland lesion, the overlap between benign and malignant lesions, presence of cystic component and oncocytic metaplasia. ${ }^{24}$ Reports have shown chronic sialadenitis as the most common non-neoplastic lesion with the overall accuracy of FNAC to be $83.8 \%$ with $77.7 \%$ sensitivity and $86.3 \%$ specificity. ${ }^{25}$ In a more recent study, the diagnostic sensitivity was $94 \%$, specificity was $97 \%$ and the accuracy was $95 \%{ }^{26}$

The use of FNA - a method of aspiration biopsy cytology continues to grow throughout the world. Improvements in using imagingand ultrasound have fuelled the growth of FNAC among both interventional radiologists and clinicians. ${ }^{27}$ In future, molecular genetics methods will probably extend the diagnostic range of FNA beyond what is currently achievable with classic cytology.

\section{CONCLUSION}

Fine needle aspiration cytology being simple quick cost- effective minimal invasive relatively less painful procedure has proven to be quite a useful tool in the investigation of head and neck region swelling which poses more challenge due to not so easy anatomical terrain for an incisional biopsy study. It has the diagnostic ability to differentiate between inflammatory, benign malignant processes and thus aid in further management effectively.

\section{LIMITATION OF THE STUDY}

The FNAC itself has its own limitations to make specific diagnosis as mentioned above in the discussion. Tissue biopsy is still considered the gold standard to make a final diagnosis in the evaluation of any swelling on the body.

\section{ACKNOWLEDGEMENTS}

I would like to express my gratitude to Mr Tara Mahat, Mr Anup Thapa, Mr Subash Shrestha from Department of Pathology and Mrs Renu from the record keeping section of Department of cytopathology, Helping Hands Community Hospital.

\section{CONFLICT OF INTEREST \\ None}

\section{FINANCIAL DISCLOSURE}

None

\section{REFERENCES}

1. Addams-Williams J, Watkins D, Owen S, Williams N, Fielder C. Nonthyroid neck lumps: appraisal of the role of fine needle aspiration cytology. Eur Arch Oto-Rhino-Laryngol Off J Eur Fed Oto-RhinoLaryngolSoc EUFOS AffilGerSocOto-Rhino-Laryngol - Head Neck Surg. 2009 Mar;266(3):411-5. DOI:10.1007/s00405-008-0751-4

2. Orell SR, Sterrett GF. Orell and Sterrett's Fine Needle Aspiration Cytology.5th ed. Elsevier Health Sciences; 2011.1p.

3. Ryd W, Hagmar B, Eriksson O. Local tumour cell seeding by fineneedle aspiration biopsy. A semiquantitative study. Acta Pathol MicrobiollmmunolSc and [A]. 1983 Jan;91(1):17-21. DOI: 10.1111/ j.1699-0463.1983.tb02721.

4. Thomas JO, Amanguno AU, Adeyi OA, Adesina AO. Fine needle aspiration (FNA) in the management of palpable masses in Ibadan: impact on the cost of care. CytopatholOff J Br SocClinCytol. 1999 Jun;10(3):20610.DOI:10.1046/j.1365-2303.1999.00187.

5. 14. Ali SZ, Cibas ES. The Bethesda System for Reporting Thyroid Cytopathology: Definitions, Criteria and Explanatory Notes. Springer US; $2010.2 p$

6. Faquin WC, Rossi ED, Baloch Z, Barkan GA, Foschini MP, Kurtycz DFI, et al. The Milan System for Reporting Salivary Gland Cytopathology. Springer International Publishing; 2018. 3p.

7. Stevenson M, C. H, Nunes T. epiR: tools for the analysis of epidemiological data Melbourne, Vic: Faculty of Veterinary Melbourne and Agricultural Sciences, The University of Melbourne 2020. Available from: https://cran.rproject.org/ web/ packages/ epiR/index.html.

8. R Core Team. R: A language and environment for statistical computing R foundation for statistical computing. Austria, Vienna. 2020.

9. Khetrapal S, Jetley S, Jairajpuri Z, Rana S, Kohli S. FNAC of head \& neck lesions and its utility in clinical diagnosis: a study of 290 cases. Thyroid. 2015;49(16.9):44

10. Gupta G, Joshi DS, Shah A, Gandhi M, Shah NR. FNAC of head and neck swellings. GCSMC J Med Sci. 2014;3(1):38-41.

11. Raina B, Misri A, Kanotra JP, Suhail M, Khajuria A, Gupta RK. Profile of fine needle aspiration cytology of thyroid nodule and its histopathological correlation. JK Pract. 2011;16:70-5.

12. Kamra HT, Agarwal R, Rana P, Kalra R, Kaur S, Duhan A, Verma S, Agarwal D. Evaluation profile of thyroid nodule by fnac in the rural population of KhanpurKalan, Sonepat, Haryana. Journal of clinical and diagnostic research: JCDR. 2014 Oct;8(10):FC16.

13. Iacob A, Zazgyva A, Ormenişan A, Mezei T, Sin A, Tilinca M. Effectiveness of fine-needle aspiration cytology in the diagnosis of lateral cervical nonthyroidtumors. Medicine (Baltimore). 2016 Aug;95(31):e4448.DOI:10.1097/MD.0000000000004448

14. Howlett DC, Harper B, Quante M, Berresford A, Morley M, Grant J, et al. Diagnostic adequacy and accuracy of fine needle aspiration cytology in neck lump assessment: results from a regional cancer network over a one-year period. J Laryngol Otol. 2007 Jun;121(6): 571-9. DOI:10.1017/S0022215106004944

15. Paker IO, Kulaçoğlu S, Eruyar T, Ergül G. Fine needle aspiration cytology of head and neck masses: a cytohistopathological correlation study with emphasis on false positives and false negatives. Kulak BurunBogazlhtisDerg KBB J Ear Nose Throat. 2013 Jun;23(3):163-72. DOI: 10.5606/kbbihtisas.2013.27048

16. Amedee RG, Dhurandhar NR.Fine-needle aspiration biopsy.The Laryngoscope. 2001 Sep;111(9):1551-7. DOI: https://doi.org/ 10.1097/00005537-200109000-00011

17. Rathod GB, Parmar P. Fine needle aspiration cytology of swellings of head and neck region. Indian J Med Sci. 2012 Apr;66(3-4):49-54. DOI: 10.4103/0019-5359.110896

18. Ishar T, Gupta RK, Khajuria A. Role of FNAC In Diagnosis of NonThyroidal Head and Neck Lesions. 2012;14(1):5. 
19. Singh S, Nigam JS, Gutpta A, Giri S, Kaur V, Singhal O, Garg A. Array of Cytological Diagnosis in Head \& Neck Fnac in Rural Population of Western UP, India. International Journal. 2014 Jul;2(2):95.

20. Akhavan-Moghadam J, Afaaghi M, Maleki AR, Saburi A. Fine needle aspiration: an atraumatic method to diagnose head and neck masses. Trauma Mon. 2013 Dec;18(3):117-21. DOI: 10.5812/ traumamon. 10541

21. Ahmad T, Naeem M, Ahmad S, Samad A, Nasir A. Fine needle aspiration cytology (FNAC) and neck swellings in the surgical outpatient. J Ayub Med Coll Abbottabad JAMC. 2008 Sep;20 (3):30-2. PMID:19610510

22. Perros P, Boelaert K, Colley S, Evans C, Evans RM, Gerrard Ba G, et al. Guidelines for the management of thyroid cancer. ClinEndocrinol (Oxf). 2014 Jul;81Suppl 1:1-122. DOI: 10.1111/cen.12515
23. Feldkamp J, Führer D, Luster M, Musholt TJ, Spitzweg C, Schott M. Fine Needle Aspiration in the Investigation of Thyroid Nodules. Dtsch Arzteblatt Int. 2016 May 20;113(20):353-9.DOI: 10.3238/ arztebl. 2016.0353

24. Tyagi R, Dey P. Diagnostic problems of salivary gland tumors. DiagnCytopathol. 2015;43(6):495-509.DOI: 10.1002/dc.23255

25. Naz S, Hashmi AA, Khurshid A, Faridi N, Edhi MM, Kamal A, et al. Diagnostic role of fine needle aspiration cytology (FNAC) in the evaluation of salivary gland swelling: an institutional experience. BMC Res Notes. 2015 Mar 27;8(1):101. DOI:10.1186/s13104-0151048-5

26. Klijanienko J, Vielh P, Batsakis JG. Salivary Gland Tumours [Internet].Karger; 2000.(Monographs in clinical cytology). Available from: https://books.google.com.np/books?id=KZd5WHE25sOC

27. Bibbo M, Wilbur D. Comprehensive Cytopathology. 3rd ed. Elsevier Health Sciences; 2008. 607p. 